\title{
Het boek Openbaring: De macht van Gods geduld
}

\author{
Author: \\ Paul B. Decock ${ }^{1}$ \\ Affiliation: \\ ${ }^{1}$ St Joseph's Theological \\ Institute, University of \\ KwaZulu-Natal, South Africa \\ Correspondence to: \\ Paul Decock \\ Email: \\ decock@sjti.ac.za \\ Postal address: \\ Private Bag 6004, Hilton \\ 3245 , South Africa \\ Dates: \\ Received: 06 June 2011 \\ Accepted: 05 Nov. 2011 \\ Published: 17 May 2012 \\ How to cite this article: \\ Decock, P.B., 2012, 'Het boek \\ Openbaring: De macht van \\ Gods geduld', HTS Teologiese \\ Studies/Theological Studies \\ 68(1), \#Art. 1103, 8 pages. \\ http://dx.doi.org/10.4102/ \\ hts.v68i1.1103
}

(c) 2012. The Authors.

Licensee: AOSIS

OpenJournals. This work

is licensed under the

Creative Commons

Attribution License.
The Apocalypse of John: The power of God's patience. John B. Thompson relates power primarily to institutions, which embody the aims of a specific social structure. However, human actions will either endorse this social structure and empower its institutions or undermine them. The Apocalypse of John attempts to use its prophetic authority to undermine the power of the institutions of the Roman Empire and of its social structure by challenging the communities to withdraw their support from these and to continue this project in their own prophetic mission to all nations. The Apocalypse challenges the symbolic universe of the Roman Empire (an important element in their social structure) and the power of its institutions with an alternative symbolic universe rooted in the Old Testament traditions of God as the creator. In this symbolic universe the throne of God with God's judgement is the institution where true power is situated and which will bring the work of creation to its fulfilment. The Empire is revealed as embodying the aims of Satan, who alienates people from God and so destroys God's creation. The communities are called upon to act according to the aims inspired by the alternative symbolic universe as lived out by Jesus (hence the emphasis on the 'works' and the reminder to 'persevere in doing the works of Jesus'[2:26]). The power of God's judgement is not yet fully experienced because in God's patience it is delayed in order to give the opportunity to the communities and all nations to bring their 'works' in tune with the aims of creation and so to undermine and 'overcome' the power of the Empire and Satan. God's imminent judgement is meant as the vibrant guarantee of the success of creation, of the value of the 'works of Jesus' and of the uselessness of the 'works of Satan'. Although the faithful may appear as powerless victims they are in fact 'agents' of God's creation.

\section{Inleiding}

In de sociale context waarin het boek Openbaring ontstond hadden goddelijke woorden groot gezag en daarom ook grote macht. ${ }^{1}$ In de geschiedenis van Israël zien we regelmatig hoe een profeet en een politieke machthebber tegenover elkaar komen te staan. In de bijbelse traditie wordt de profeet dikwijls voorgesteld als het slachtoffer van de machthebbers, maar uiteindelijk zijn de profeten toch machtiger. Dit komt duidelijk naar voren in de volgende voorbeelden: Mozes tegenover Farao, Jeremia tegenover Zedekia, Johannes de Doper tegenover Herodes, Jezus tegenover Pilatus.

Macht kan gezien worden binnen het kader van de interactie tussen, ten eerste, een dominante sociale structuur; ten tweede, de instellingen die de doelen van die sociale structuur bevorderen en beschermen, en ten derde, handelende personen. ${ }^{2}$ De handelende personen kunnen de doelen dienen en worden dan beschermd en bevoorrecht door de instellingen, of ze kunnen tegen de doelen ingaan en dan ondervinden ze de beperkende en straffende macht van die instellingen. De handelende personen hebben ook macht in die zin dat hun 'werk' de sociale structuur en instellingen kan ondermijnen, want 'social structure "functions" only in so far as agents reproduce etablished institutions thereby constituting the structural conditions for institutional persistence' (Thompson 1981:149). Terwijl de instellingen van het Romeinse Rijk de gemeenten zien als hinderpalen voor hun doelen en daarom hun macht uitoefenen tegen hen, antwoordt Johannes met een aanval op het symbolisch kader van hun sociale structuur. Terwijl de keizerlijke propaganda het Rijk voorstelt als bestemd voor een 'goddelijke' taak, ${ }^{3}$ roept Johannes een alternatieve sociale

1.Oracles and divination played a regular and significant role in the lives of Greeks and Romans from earliest times down to the triumph of Christianity over competing pagan religions in the fourth century A.D.' (Aune 1983:23).

2.Ik volg de inzichten van Thompson (1981:143-149). Als voorbeeld van een sociale structuur verwijst hij naar de kapitalistische sociale formatie (1981:145); ook schrijft hij, 'Just as the concept of the unconscious can be justified in terms of its capacity to disclose a domain of experience, so too the justification of the notion of social structure consists in its ability to articulate a realm of being which lies at the base of social and political consciousness' (1981:206). Dit wordt als volgt verduidelijkt: 'In adopting this approach to the status of social structure, I wish to steer a course between a reductionist account of social structure which would treat it as a mere heuristic define the conditions for the persistence of a social formation and for the variation of its component institutions, social structure has define the conditions for the persistence of a social for
the status of conditions of possibility' $(1981: 239$, n. 55)

3.Zoals, bijvoorbeeld, in de Aeneas van Virgilius. 
structuur op die zijn wortels heeft in de bijbelse traditie van de schepping, waarin de macht van alle instellingen in de wereld afhankelijk is van Gods instellingen, vooral van Gods rechtspraak. Verder roept hij iedereen in de gemeenten op om te handelen volgens de doelen van God zoals die door Jezus zijn voorgeleefd (Op 2:26), ${ }^{4}$ doelen die zeker 'spoedig' gerealiseerd zullen worden door Gods oordeel.

Binnen de geloofsgemeenschap hebben de profeten verder nog het probleem hun geloofsgenoten te overtuigen van de waarheid van hun visie op de sociale structuur, vooral als andere profeten andere visies en andere wegen voorstaan. Voor Johannes was dit het geval. De brieven uit Openbaring wijzen op de invloed van valse profeten in de gemeenten (2:14-15, 20-24) en in die zin worden het gezag en de macht van Johannes bedreigd. De grote tegenstander van Johannes is echter de Pseudoprofeet $(16: 13 ; 19: 20 ; 20: 10)$, die voor het eerst verschijnt in Openbaring 13:11-17. ${ }^{5}$ Hij verdedigt de sociale structuur van het Romeinse Rijk en hij is machtig door de macht van het Rijk, maar Johannes wil zijn toehoorders overtuigen dat die macht niet van God komt maar van de Draak die hem, samen met het eerste Beest, macht 'gegeven' heeft $(13: 2,4,5,7,14,15)$. Tegenover die macht van de Draak, het Beest en de pseudo-profeet (en de valse profeten in de gemeenten) openbaart Johannes de macht van God en van het Lam en roept hij de gemeenten op om hun profetische taak in de schepping op te nemen.

Oordelen wie een ware profeet is en wie niet, blijkt heel moeilijk te zijn omdat de criteria geen duidelijke uitkomsten geven. ${ }^{6}$ Het gezag en de macht van een profeet en van een profetische tekst binnen een gemeenschap hangt dus af van een moeilijk proces van beoordeling, namelijk, van onderscheiding van de geesten (1 Thes 5:20-21). Daarom moet het boek Openbaring zijn waarachtigheid als woord van God aantonen om zijn gezag te laten gelden in de gemeenten. Het boek begint dus met het getuigenis dat dit boek de openbaring van God is. De waarachtigheid van die woorden wordt later driemaal bevestigd: 19:9; 21:5; 22:6. Zeven maal worden de gemeenten aangemaand om de brieven serieus te nemen als woorden van de Geest $(2: 7,11,17,19 ; 3: 6,13,22)$. Net vóór het einde van het boek worden de lezers bedreigd met goddelijke straffen als ze iets zouden durven toevoegen of weglaten (22:18-19). ${ }^{7}$ De overtuigingskracht van het boek

4.Johannes roept op om de 'werken' van Jezus te doen; de 'werken' genieten speciale aandacht in Openbaring $(2: 2,5,6,19,22,23,26 ; 3: 1,2,8,15 ; 9: 20 ; 14: 13 ; 16: 11$; $18: 6 ; 20: 12,13 ; 22: 12$. Zie Decock (2007). De werken van Jezus en zijn volgelingen hebben macht omdat door die werken de dominante sociale structuur overwonnen wordt.

$5 . . .$. the most likely solution is that the beast from the earth represents the imperia priesthood, which was centrally concerned with promoting the imperial cult... (Aune 1998:756).

6.Verschillende criteria worden aangeduid in Deuteronomium 13:1-6; 18:20-22; 1 Koningen 22:28; Jeremia 28:9; 32:6-8; Did. 11:7-12. Zie Hibbard (2011:353), die aantoont hoe Jeremia het criterium van accurate voorspelling afwijst (Jer 18:7-0): ... the predictive capacity of prophecy receded in favor of a more strident call for changes in religious attitude and political policy.'

7.Vergelijk met Did. 4:13 and Barn. 19:11; '...Joh is zich bewust een geschrift met goddelijke garantie geschreven te hebben, dat is iets heiligs, daar mag men evenmin

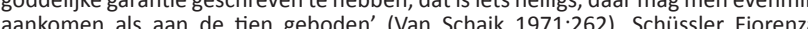
aankomen als aan de tien geboden' (Van Schaik 1971:262). Schüssler Fiorenz (2001:8) gaat verder: 'Such a powerful adjuration indicates that John is not sure how his work will be received and respected. Morover, he seems to forestall the testing of his work, .... Haar bedoeling is echter te reageren tegen fundamentalistisch benaderingen van de tekst die nadenken en beoordeling overbodig achten: 'The result is a lack of critical theological ability and spiritual practice to adjudicate scriptural texts' (2001:9) moet echter komen van het werk in zijn geheel, van de kracht van de beelden met hun wortels in bijbelse traditie, van de centrale oproep om God alleen te aanbidden (14:7; 19:10; 22:9), van de structuur van het werk; de overtuigingskracht van het werk moet ook komen van een visie die de ervaring van de gemeenten raakt, die zin geeft aan het lijden van de hele schepping en hoop op een heilzame toekomst voor de gemeenten en voor heel de schepping. ${ }^{8}$

Dit artikel beperkt zich tot drie aspecten van macht. In de eerste plaats wordt de macht van God in Openbaring gesitueerd binnen het symbolisch kader van Gods scheppingswerk en van het conflict in de schepping dat overwonnen zal worden door Gods oordeel. In een tweede stap zien we hoe Openbaring het conflict in de schepping - onmiddellijk ervaren door de macht van het Romeinse Rijk - openbaart als een conflict dat zijn uiteindelijke wortels heeft in de Draak, een opstandig schepsel dat zich die macht onrechtmatig toegeëigend heeft. De Draak wordt het symbool van de 'zonde,' maar ook van de uiteindelijke machteloosheid van zonde. Een derde stap geeft aandacht aan het vijfde zegel (6:9-11). Openbaring verzekert de gemeenten dat het oordeel zeker zal komen (reeds in 1:7), maar in deze korte tijd voor het oordeel worden de gemeenten opgeroepen om te volharden in hun dienst aan God en hun getuigenis in de schepping. Als getuigen ervaren de gemeenten niet alleen de macht van God aan het werk in hun profetische dienst, maar ook hun tijdelijke onmacht als gevolg van Gods tijdelijk geduld. Ondanks deze fundamentele onmacht in dit aardse leven kunnen ze toch de Draak overwinnen door hun trouw aan God tot de dood, door hun 'werken,' namelijk door hun deelname aan de 'werken van Jezus' (2:26), het Lam, de trouwe getuige (1:5). De profetische dienst van de gemeenten aan de wereld is bedoeld om alle volken, naties en talen op te roepen om God en niet het Beest te aanbidden zodat allen deel kunnen hebben aan de nieuwe, voltooide schepping.

\section{De macht van God en Jezus Oordeel en schepping}

In het symbolisch kader dat Johannes neerzet als antwoord op de macht van het Romeinse Rijk worden de toehoorders geconfronteerd met de instelling van de hemelse troon waar alle ware macht geconcentreerd is, in tegenstelling tot de troon van de keizer, die eigenlijk de troon van Satan vertegenwoordigt $(2: 13 ; 13: 2 ; 16: 10){ }^{9}$

Vanaf het begin van het boek worden de lezers herinnerd aan Gods almacht (1:8) en aan de almacht van Jezus Christus $(1: 5,6)$. Volgens Openbaring zal die almacht zich spoedig tonen aan alle mensen in het komende oordeel $(1: 1,3,7)$, het dominante thema tot het einde van Openbaring 20.

8.Carey (2001:173-180) toont aan hoe Johannes zichzelf retorisch identificeert met de gemeenten terwijl hij zijn tegenstanders retorisch neerhaalt. 'In authorizing his vision, he constructs an unstable ethos. John's ethos is at once egalitarian and authoritarian, inviting and exclusivist. John reaches out to the audience, yet locates himself as the sole mediator of truth; he calls his opponents to repentance, yet depicts them in the most abject terms.' Hij voegt er echter aan toe: 'Perhaps John's ambivalence is endemic to Christian discourse.'

9. De troon wordt reeds vermeld in 1:4 en het woord komt 47 keer voor in Openbaring tegen 62 keer in heel het Nieuwe Testament. 
Vanaf de eerste verschijning van Jezus in Openbaring 1:9-20 wordt Jezus voorgesteld als de komende rechter, die echter nog niet oordeelt maar oproept tot volharding en bekering met het oog op het komende oordeel. Het oordeel en de redding zijn voorgesteld als zeer nabij $(1: 1 ; 22: 6,10$, $12,20)$ en als motief om deze korte tijd te zien als een tijd van bekering, strijd en volharding. ${ }^{10}$ De eerste verschijning van Jezus roept Daniël 7:13-14 in herinnering waar iemand zoals een mensenzoon macht ontvangt ${ }^{11}$ van God zodat alle volkeren hem dienen; het zwaard uit zijn mond (1:16; ook $2: 12,16$ en $19: 15,21)$ is een beeld van het komende oordeel zoals in Jesaia 11:4 (Beale 1999:211-212). ${ }^{12}$ In de brieven (Op 2-3) wordt iedere gemeente aangesproken, aangemoedigd of uitgedaagd om te overwinnen met het oog op het komende heil. Het oordeelsthema is prominent aanwezig; Jezus komt onverwachts zoals een dief (3:3; vergelijk 16:15); zelfs als strijder (2:16; vergelijk 19:11-16). Deze aan de gemeenten gerichte oproep door Jezus, de rechter (en strijder, 2:16), wordt in een breder, kosmisch perspectief geplaatst in Openbaring 4-22. In Openbaring 4 ziet Johannes de troonzaal in de

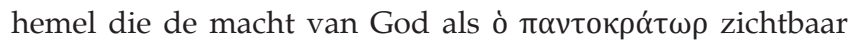
maakt; het tafereel eindigt met een verwijzing naar Gods scheppingsdaad als de grond voor de erkenning van zijn almacht (4:11). Openbaring 5 toont de volmacht van Christus als rechter en strijder, die het komende oordeelsplan van God ontvangt (het boek met de zeven zegels). Dit plan wordt ontvouwd in twee fasen (eerst de zeven trompetten, die maar een derde deel van de schuldige wereld treffen, en dan de zeven offerschalen die de schuldige wereld volledig treffen). Dit oordeel wordt nog eens geillustreerd in de voorstelling en het vonnis van Babylon, in de finale val van de Beesten en de Draak en van allen die hen volgden. Uiteindelijk, na het oordeel, kan het werk van God voltooid worden (21:5-6): een nieuwe hemel en een nieuwe aarde, de neerdaling van het nieuwe, heilige Jeruzalem.

Het komende oordeel moet echter gezien worden in de bredere context van de schepping. De macht van de rechter is eigenlijk de macht van de schepper en de bedoeling van het oordeel is om de schepping tot voltooiing te brengen. Het thema van de schepping komt daarom regelmatig voor in Openbaring:

- God is de schepper van alles, hemel, aarde en zee met al wat erin is: $4: 11 ; 10: 6 ; 14: 7$

- Christus is het begin of principe van Gods schepping: 3:14

- de wereld en de dingen in de wereld worden schepsels genoemd: 5:13; 8:9

10.'We wait for an end that never comes. And why should it? John would have the reader engaged in the end, to endure and to conquer, so why should he provide an ending that would let us abandon our posts?' (Barr 2001:112).

11.Lambrecht (1998:218): 'It is our firm belief that by breaking the seals and opening the book the Lamb not only communicates the fixed purposes of God's eschatological plan [as maintained by Biguzzi 1996]; this revelation is also and at the same time visionary "realization". No doubt, one has to add with much emphasis that the realization is far from complete. Only the preparation of God's punitive intervention is taking place in heaven or in creation; the day has come but its wrath is still checked.

12.Andere symbolen van macht: hij houdt de zeven sterren in zijn rechterhand (1:16) hij heeft de sleutels van de dood en Hades (1:18). Verder wordt Jezus voorgesteld als iemand die deelt in de macht en majesteit van God: 'Using this combination of imagery, which originally referred to two figures in Dan. 7:9-14, one "like a son of man" (Dan 7:13) and the Ancient of Days (7:9), the author has virtually equated man" (Dan 7:13) and the Ancient of Days (7:9), the author has virtually equated
the two figures' (Aune 1997:116). In diezelfde zin 1:17-18: de eerste en de laatste; de levende.
- Gods woede en oordeel is gericht tegen hen die de aarde vernielen: 11:18; 19:2

- de voltooiing van Gods werk is de nieuwe hemel, de nieuwe aarde, het nieuwe Jeruzalem: $21: 1-8 .^{13}$

Zoals Levenson (1994:14) het stelt, '... the stability of nature is not intrinsic; it is only a corollary of God's faithfulness.' De slechte verhouding van de schepping tegenover de Schepper brengt het gevaar met zich mee dat de schepping terugvalt in de chaotische toestand van het begin, zoals blijkt uit Genesis 6:5 en 7:11. Wat verwacht wordt van de schepselen is traditioneel uitgedrukt in de vrees voor God $(11: 18 ; 14: 7$; $15: 4 ; 19: 5)$ en de exclusieve aanbidding van God $(14: 7 ; 15: 4$; 19:10; 22:9). Die vrees voor en aanbidding van God alleen moet positief uitkomen in handelingen die het doel van Gods schepping bevorderen volgens de norm van de 'werken' van Jezus (2:26). Daarom zullen de mensen geoordeeld worden volgens hun 'werken' (14:13; 18:6; 20:12-13; 22:12), zoals ook de gemeenten in de brieven beoordeeld worden volgens hun 'werken' $(2: 2,5,6,19,22,23,26 ; 3: 1,2,8,15){ }^{14}$

Volgens Openbaring is de situatie dramatisch; de schepping wordt bedreigd (11:18; 19:2). De optimistische propaganda van het Romeinse Rijk ${ }^{15}$ is een illusie; het Rijk zelf maakt onderdeel uit van die bedreiging. Gods antwoord is het komende oordeel en de oorlog tegen de Draak, het Beest, de valse profeet, en tegen allen die hen volgen. Oordeel en oorlog waren de twee gebruikelijke instellingen waardoor onrecht kon worden hersteld. Deze twee beelden zijn met elkaar vervlochten in Openbaring. Over Jezus, de ruiter op het witte paard, wordt gezegd: 'die een rechtvaardig vonnis velt en een rechtvaardige strijd voert' (19:11). De nadruk op rechtvaardigheid is opvallend hier en het is ook opvallend hoe God en het Lam regelmatig geprezen worden voor hun rechtvaardigheid, voor hun optreden tegen onrecht. ${ }^{16}$ Het is in die zin dat Christus, de ruiter op het witte paard, voorgesteld wordt als koning der koningen en heer der heren (19:16; ook in 17:14). Gods scheppingswerk wordt zeker voltooid wanneer het de juiste tijd is voor Gods woede en voor het oordeel, wanneer God eigenhandig zijn grote macht uitoefent en daarmee gaat regeren als koning $(11: 15,17-18) .{ }^{17}$

God en het Lam worden geprezen om hun wijsheid en macht (5:12; 7:12); wijsheid om te kunnen beoordelen wat recht is en macht om de oordelen uit te voeren: onschuldigen beschermen en schuldigen straffen, en zo een einde maken

13.'Indeed, "kainos", ('new'), as we have seen, refers predominantly to a change in quality or essence rather than to something new that has never previously been in existence. The usage of "kainos", is especially found in NT contexts describing in existence. The usage of 'kainos", is especially found in NT contexts
eschatological or redemptive-historical transitions' (Beale 1999:1040).

14.'The "works" for which this church is first recognized are not mere general deeds of Christian "service" but works of persevering witness to the outside world. That this is specifically meant is discernible from the fact that when "love," "faith," and "endurance," especially "endurance and faith," appear elsewhere in the book they almost always refer to persevering witness,' aldus Beale (1999:260).

15. Horatius, Carmen Saeculare; Virgilius, Vierde Ecloge; het monument van de Ara Pacis in Rome.

16.Openbaring 15:3; 16:5, 7; 19:2; Openbaring 19:11; Openbaring 15:4; 19:8. Beale (1999:795): 'God's "righteous and true ways" in 15:2 are parallel with "great and marvellous works," showing that God's sovereign acts are not demonstrations of raw power but moral expressions of his just character. His redemption through Christ has brought to supreme expression how he demonstrates his justice.'

17.De 'komende' $(1: 4,8 ; 4: 8)$ verwijst naar God die komt om te oordelen; dat is het grote gebeuren waarover 1:1 en 22:6 spreken. Het 'komen' van Jezus in 1:7 is een duidelijke allusie op Daniël 7:13; ook 3:11; 16:15; 22:7, 12, 20. 
aan het onrecht. ${ }^{18}$ Rechtspraak is een van de instellingen waar men ziet dat 'macht om' en 'macht over' als complementair gezien moeten worden. ${ }^{19}$ In de rechtspraak is 'macht om' duidelijk het belangrijkste aspect van macht; het doel is een rechtvaardige samenleving bewerken. Maar rechtbanken confronteren zich met onrecht en zoeken daarbij geen consensus tussen de rechter en de aangeklaagde. De rechter oordeelt volgens wetten die geïnspireerd zijn door het dominante symbolisch kader of de dominante sociale structuur en als zodanig oefent hij recht uit 'over' hen die de doelen van die sociale structuur tegenstaan. Johannes probeert de rechtspraak van het Rijk met zijn sociale structuur te ondermijnen, maar hij behoudt de instelling van de rechtspraak als die van God en het Lam met de twee aspecten: 'macht om' de schepping tot voleinding te brengen en 'macht over' alles wat die voleinding tegenwerkt. Die 'macht over' heeft echter specifieke eigenschappen. Allereerst, het oordeel wordt als zeer nabij voorgesteld maar er is nog een korte tijd gegund, ${ }^{20}$ een genadevolle gelegenheid tot bekering. Iedereen kan ontkomen aan de negatieve uitwerking van het oordeel door zich te bekeren; iedereen kan deel hebben aan het nieuwe Jeruzalem. Openbaring geeft zelfs hier en daar een hoopvolle indruk: in het nieuwe Jeruzalem zien we hoe de volkeren zich afgewend hebben van de aanbidding van het Beest en nu de ware God aanbidden..$^{21}$ De brieven aan de gemeenten eindigen ook op hoopvolle toon door het perspectief van de overwinning naar voren te brengen, zelfs voor de gemeenten die zeer negatief beoordeeld worden: 'aan hen die overwinnen ...' $(2: 7,11,17,26 ; 3: 5,12,21)$. Ten tweede, 'macht over' toont zich op een spectaculaire manier in de plagen als goddelijke vermaningen tot bekering, maar deze teksten zijn niet hoopvol (9:20-21; 16:9, 11). Ten derde, uitoefening van 'macht over' wordt door de engel van de wateren en door stemmen van het altaar als rechtvaardig geprezen en de straffen als passend (16:5-7; zie ook 15:3-4; 19:1-2)

18.Straf, nu zoals in de tijd en cultuur van Johannes, heeft - ideaal gezien - een drievoudige functie: het brengt de onrechtvaardige handelingen tot een einde; drievoudige functie: het brengt de onrechtvaardige handelingen tot een einde;
het herstelt het aangedane onrecht door vergelding; het dient als afschrikmiddel het herstelt het aangedane onrecht door vergelding; het dient als afschrikmiddel tegen verder onrecht (voor Israel, zie Bovati 1994:382-387). Sedert de Verlichting
wordt het fysisch geweld van vroegere en andere culturen bij deze drie functies aangevoeld als onaanvaardbaar; de vraag van emotioneel geweld krijgt echter nog weinig aandacht.

19.'However, the framework sketched above suggests that these two views are neither wholly incompatible with one another, nor jointly sufficient to account for the phenomenon of power. I shall maintain that the principal locus of power is the level of institutions, for power is primarily an institutionally endowed con capacity for the pursuit of specific ends' (Thompson 1981:146). Schüssler Fiorenza 2008:165-167) gebruikt deze twee uitdrukkingen als contrasterende kenmerken "Nevertheless, inscribed in scripture is not only the rhetoric of empire as "powe "por an alternative rhetoric of power that understands power as "power to," as creative, liberating "power for."

20.Gods oordelend en reddend handelen is zeer nabij: 'spoedig' $(1: 1 ; 11: 14 ; 22: 6$; $2: 16 ; 3: 11 ; 22: 7,12,20)$, 'een korte tijd' (6:11), 'geen tijd meer' (10:6). Hemelse stemmen verkondigen dat de heerschappij van de Heer en zijn Gezalfde gekomen is $(11: 15 ; 12: 10)$. Van de troon wordt verkondigd: 'het is gebeurd' $(16: 17 ; 21: 6)$ Maar in feite is het nog niet gebeurd in de ervaring van de gemeenten. Volgens Barr (2001:112) 'in this story the awaited end never quite comes. Faced with this ending, the reader must reconsider the story's meaning, must reread the story'. Met andere woorden, de toehoorders moeten de 'story' dringend laten spreken in hun huidige ervaring.

21.Bauckham (1993:238-337) heeft overtuigend aangetoond dat de bekering van de volkeren een centraal thema is van Openbaring. Maar dit betekent niet dat

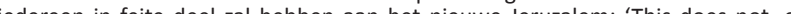
course, mean that Revelation expects the salvation of each and every human course, mean that Revelation expects the salvation of each and every human being. From 21:8, 27; 22:15, it is quite clear that unrepentant sinners have no place in the New Jerusalem' (1993:313, n. 100).
De grote tegenstanders van Gods scheppingsproject zijn - en in die orde - de Draak, het Beest, de Pseudoprofeet, Babylon, en allen die door Babylon misleid zijn. Het is 'over hen' dat God zijn macht zal uitoefenen. Openbaring 4-22 contrasteert de ware macht van God met de schijnbare macht van het Romeinse Rijk, maar uiteindelijk met de schijnbare macht van de Draak.

\section{De schijnbare macht van het Beest en de Draak}

De houding tegenover de politieke macht in de vroege kerk was complex. Ondanks het feit dat Jezus ter dood veroordeeld was door Pontius Pilatus, als een van de vele rustverstoorders in 'het rijk van vrede' van die tijd, ondervonden sommige gemeenten toch 'vrede en welvaart' in the Rijk (waarschijnlijk de gemeente van Laodicea: Op 3:14-22). Romeinen 13 is pragmatisch en ziet het nut van gezagdragers maar duidt aan dat hun gezag afhangt van God (ze zijn dienaren van God: vv. 4 en 6). Volgens Johannes 19:11 leest Jezus Pontius Pilatus de les: Jezus antwoordde: 'De enige macht die u over mij hebt, is u van boven gegeven.' Openbaring daarentegen (13:2-8) ziet de macht van het Romeinse Rijk als een gave van de Draak. De Draak is zeer vrijgevig met macht, ${ }^{22}$ een thema dat we zelfs terugvinden in de verzoekingen van Jezus (Mat 4:8-10; Luk 4:5-8). Daar antwoordt Jezus met een tekst uit Deuteronomium $(6: 13 ; 10: 20)$ die overeenkomt met het eeuwige evangelie van Openbaring 14:7 en met de boodschap van de derde engel in 14:9-11: de aanbidding van God alleen en niet de afgodendienst van Satan.

Openbaring focust op de Draak als de oorsprong van de politieke macht van het Rijk. De Draak wordt voorgesteld als bron en model van alle tegenstand tegen God. De Draak is daarom de eerste die zijn opwachting maakt (12:3), nog vóór het Beest uit de zee en het Beest uit de aarde (Op 13). Het is dan ook in de omgekeerde volgorde dat ze geëlimineerd worden in 'de vuurpoel met brandende zwavel' $(19: 20 ; 21: 8)$.

Op het eerste gezicht is de Draak indrukwekkend, vreesaanjagend, destructief, met een buitengewone macht (12:3-4), maar onmiddellijk wordt duidelijk dat al zijn plannen één voor één in de war lopen: de pasgeboren zoon wordt weggevoerd naar Gods troon (12:5); de oorlog met Michael verdrijft hem uit de hemel en werpt hem neer op de aarde (12:9); de vrouw ontsnapt aan hem in de woestijn (12:13-16). Maar hij blijft gevaarlijk: nu is hij woedend omdat hij weet dat zijn tijd kort is (12:12) en begint hij oorlog te voeren tegen de afstammelingen van de vrouw, zij die 'de geboden van God onderhouden en vasthouden aan het getuigenis van Jezus' (12:17). ${ }^{23}$

De ultieme oorzaak van de machteloosheid van de Draak, en van al zijn volgelingen, wordt duidelijk gemaakt door de identificatie van de Draak als:

22.Zie de herhaling van het werkwoord 'geven' in Openbaring 13.

23.'The focus of the phrase may be on Jesus' testimony to God, which the church is to reproduce' (Beale 1999:679). 
Zij werden uit de hemel weggejaagd. De grote draak, de oude slang (ook wel duivel of satan genoemd) die alle mensen ter wereld verleidt, is met zijn engelen op de aarde gegooid. (Op 12:9)

Hij pakte de draak (de oude slang, satan, de duivel) en boeide hem voor duizend jaar. (Op 20:2)

De tekst die hier in herinnering geroepen wordt is eerst en vooral Genesis 3 (zie ook Wijsheid 3:24; 2 Kor 11:3). Genesis 3:1 stelt ons de slang voor als een buitengewoon wijs of sluw schepsel, maar toch een schepsel. Zijn wijsheid wordt gebruikt om de mensen weg te leiden van hun vertrouwen en gehoorzaamheid aan God; hen wordt wijsgemaakt dat ze door Gods woord te veronachtzamen aan God gelijk kunnen worden. Bauckham (1993:185-198) stelt dat Johannes niet verwijst naar één enkele bestaande mythe, maar dat hij een nieuw symbool schept 'exploiting the vital symbolism of his readers' environment' (1993:198). ${ }^{24}$ Hij verwijst echter niet naar de exegetische tradities verbonden met Jesaja 14 en Ezechiël 28. Daar vinden we ook het thema van de buitengewone figuren, zoals de slang, die hun gaven echter niet erkennen als komende van God en zich verheffen om de macht van God te grijpen (Jes 14:13-14; Ez 28, 2, 6, 9), maar om die reden neergeworpen worden. In de vroegchristelijke literatuur waren deze teksten verbonden met het thema van de val van de opstandige engelen en Lucifer (Jes 14:12). ${ }^{25}$ Het is best mogelijk dat deze teksten en deze interpretatie meespelen in de voorstelling van de Draak uit Openbaring.

Belangrijk is dat het hier gaat om een schepsel van God dat ondanks de vele gaven zich van God afkeert, zich almachtig waant en goddelijke aanbidding opeist. Het gaat hier niet om een metafysisch dualisme maar zeer duidelijk om een ethisch dualisme. ${ }^{26}$ God als de schepper van alles, 'die is, was en zal komen, de almachtige', heeft geen gelijke. ${ }^{27}$ De Draak, het Beest en Babylon leven in een illusie van grootheid en macht $(13: 2,5,13 ; 17: 1,5,18 ; 18: 2,10,16,18,19,21 ; 19: 2)$. Babylon 'zegt bij zichzelf: Ik zit hier als een koningin, niet als een arme weduwe. Mij zal niets gebeuren!' (18:7). De gemeente van Laodicea is een miniatuur van Babylon:

$\mathrm{U}$ zegt dat $\mathrm{u}$ rijk bent, dat $\mathrm{u}$ alles hebt wat $\mathrm{u}$ wilt en niets meer nodig hebt. U beseft niet hoe ongelukkig $\mathrm{u}$ bent, hoe armzalig, berooid, blind en naakt. (Op 3:17)

De Draak, samen met zijn volgelingen, wordt verder voorgesteld als iemand die erop uit is te moorden (12:3-4,

24. The Dragon is a symbol whose power derives from a variety of associations. He is the ancient serpent who initiated humanity's estrangement from God with the is the ancient serpint who initiat human' bait of becoming like gods. He is the symbol of the false gods of Asian paganism, ... He is the dragon who lies in wait for the birth of the divine here return to slay him. He is the twisting serpent Leviathan whom the sword of God will destroy at the final elimination of evil' (Bauckham 1993:198)

25.Tonstad (2006:69-76) verdedigt met recht het belang van deze twee teksten voo Openbaring 12. Dat die interpretatie gevonden wordt in de werken van Origenes, ten hoogste 150 jaar na Openbaring, kan een goede aanduiding zijn dat hij verwijs naar bestaande christelijke en Joodse tradities. Een exegetische traditie over de val van de engelen kan men al vinden in 1 Henoch 6-8 als interpretatie van Genesis 6 .

26.In die zin volgt Openbaring de traditie van Genesis 1:21 waar de grote zeemonsters door God geschapen zijn; ook Job 40:15, waar Behemot, en bij implicatie ook Leviathan, een schepsel is van God. De zonde en wat eruit volgt zijn het werk van Gods schepsels, zowel bovenmenselijke als menselijke.

27.Zie de uitdrukkingen in $1: 4,8 ; 4: 8 ; 11: 17 ; 16: 5$. De uitdrukkingen in $17: 8$ en 11 worden gewoonlijk beschouwd als parodie: het Beest zal het oordeel niet overleven (zie Aune 1998:939 die grafisch aantoont hoe 'vernietiging' het eindpunt vormt van 17:8a en 11a).
$15),{ }^{28}$ oorlog te voeren $(12: 7,17 ; 13: 7 ; 16: 14 ; 19: 19 ; 20: 7-10)$ en te misleiden $(12: 9 ; 13: 14 ; 18: 23 ; 19: 20 ; 20: 3,8,10)$. In het beeld van het oordeel functioneert de Draak als de aanklager $(12: 10)^{29}$ in contrast met Michaël als de verdediger.

Dit betekent dat Johannes de oorzaak van het kwaad in de wereld niet beperkt tot de zonden die mensen doen; de zonden van de mensen zijn een deelname aan zondige menselijke structuren (de twee Beesten, het Rijk en zijn valse profeten) en uiteindelijk aan de zonde van de bovenmenselijke figuur van de Draak. ${ }^{30}$ De bekering waartoe Johannes oproept betekent zich afkeren van Babylon (18:4-5), weigeren de Draak en het Beest te aanbidden (13:4, 8, 11-15; 14:9), maar God aanbidden (14:6-7) en 'vasthouden aan de geboden van God en aan de trouw van Jezus' (14:12). ${ }^{31}$

Met dit alternatief symbolisch kader wil Openbaring de propaganda en de macht van het Rijk ontmaskeren.

\section{Het vijfde zegel $(6: 9-11)^{32}$ De macht van Gods geduld}

Er is een correspondentie tussen het vijfde zegel (6:9-11) en 19:2, waar een grote menigte in de hemel God looft omdat het oordeel en de straf waarvoor de martelaren baden werkelijkheid geworden is. De bewoording van het gebed

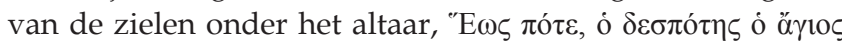

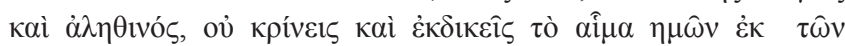

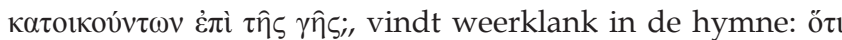

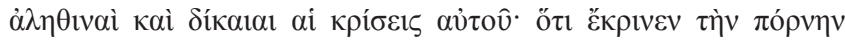

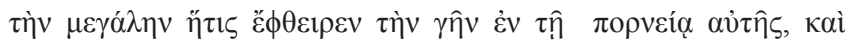

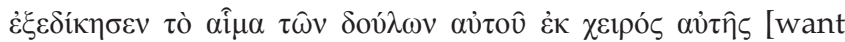
waarachtig en rechtvaardig zijn zijn oordelen, want Hij heeft de grote hoer geoordeeld, die de aarde met haar hoererij verdierf, en Hij heeft het bloed zijner knechten van haar hand geëist]. De twee werkwoorden, 'oordelen' en 'rechtmatig straffen' vormen een inclusie. Het boek Openbaring kan verstaan worden als de openbaring van Gods antwoord op 28.Vergelijk met Wijsheid 2:24; Johannes 8:39-47 (moordenaar en misleider).

29.Zie Beale (1999:661-663); volgens Aune (1998:700) 'in rabbinic sources ... one of the standard epithets of Satan (m. 'Abot 4:11; Tg. Exod. 32:19; Str-B, 1:141-42)'.

30.Tate (1992:471-472) verwijst naar het werk van De Boer (1988), die twee lijnen onderscheidt in de apocalyptische eschatologie, de ene noemt hij de kosmologische en de andere de forensische: 'The first track characterizes the world as under the dominion of evil, angelic powers, responsible for human sinfulness, death, and the usurpation of God's sovereign rights. Some sort of "angelic fall" is mentioned or alluded to with some frequency' (bl. 85). De 'forensic track' s mentioned or alluded to with some frequency' (bl. 85). De 'forensic track benadrukt dat de mensen de grootste verantwoordelijkheid dragen voor zonde n dood; het zijn de mensen die de wereld tot een 'all-embracing sphere of death' (bl. 87) gebracht hebben door hun rebellie tegen de wil van God. De Boer duidt aan dat die twee lijnen niet altijd duidelijk te onderscheiden zijn; 'like railway racks, [they] may lie parallel, crisscross, or overlap, even in a single work' (bl. 85) Volgens Tate (1992:472), 'the analysis of these two forms seems to me to be a valuable interpretative tool. In my judgment, the content of the Old Testament lies mainly along track 2 , with limited elements of the cosmological track. Non-human agents may be involved now and then, and there are metahuman dimensions of sin, evil, and salvation (e.g., in Job and Daniel 7-12), but the main thrust in the Old Testament moves along the line of divinely endowed human power for good and evil. The emphasis shifts in much of the New Testament, but the two tracks remain intertwined.

31.Zie ook 12:17. Tonstad (2006) verdedigt de subjectieve genitief, de trouw van Jezus, als de meest passende interpretatie, alhoewel de meeste vertalingen en commentaren de objective genitief verkiezen; zijn argumentatie steunt vooral op com zijn narratieve benadering van Openbaring. Hij vertaalt dit deel van het vers als 'those who hold on to the commandments of God as revealed by the faithfulness de subjectieve genitief ingesloten is.

32. Heil (1993) toont de belangrijke rol van deze scène in Openbaring. 
het gebed van de martelaren om recht en redding. Dit kan ook een antwoord zijn op de gemeenten die het gebed van de martelaren het hunne maken. ${ }^{33}$ Tegelijkertijd is de 'evocatie' van het oordeel en de oorlog een waarschuwing gericht aan iedereen die niet gereed is; het oordeel zal komen zoals een dief in de nacht $(3: 3 ; 16: 15)$.

De vraag van de martelaren is: wanneer zal God zijn rechterlijke macht uitoefenen ten voordele van de gelovigen tegen de 'bewoners van de aarde'? ${ }^{34}$ Het thema van de tijd van dat oordeel verschijnt al in het eerste vers van het boek: 'wat er binnenkort gebeuren moet' (ook in 22:6). Het antwoord in 6:11 geeft wel aandacht aan de tijd maar op een vage manier:

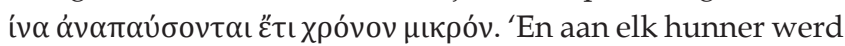
een wit gewaad gegeven, en hun werd gezegd, dat zij nog een korte tijd moesten rusten, totdat ook het getal vol zou zijn van hun mededienstknechten en hun broeders, die gedood zouden worden evenals zij. ${ }^{\prime 35}$ Belangrijker is echter de reden waarom God niet onmiddellijk zijn rechterlijke macht uitoefent in de schepping, ondanks het lijden, het onrecht en de verwoesting van de aarde: het aantal dienaren en broeders en zusters die nog moeten sterven in de dienst van het woord van God en van het getuigenis moet eerst volledig zijn. Met andere woorden, ondanks de voortdurende 'opstand' tegen God en het geweld tegen de getuigen en tegen de schepping zelf blijft God zijn hand uitsteken naar de mensen. ${ }^{36}$ Dit komt in zekere mate overeen met 2 Petrus 3, waar sprake is van het geduld van God die niet wil dat ook maar iemand verloren gaat en dat iedereen gered wordt. Gods geduld wordt niet genoemd in Openbaring, maar het beeld van Openbaring 3:20 kan gezien worden als een uitdrukking van Gods geduldig 'aankloppen,' ondanks het feit dat de gemeente van Laodicea in dezelfde illusie leeft als Babylon. De verschijning van Jezus als de machtige rechter die in 1:9-20 nog niet komt om te oordelen maar om op te roepen tot bekering of volharding versterkt dit perspectief. In die zin is het ook begrijpelijk waarom alle brieven (Op 2-3) eindigen op een positieve toon met de aanmoediging, 'aan iedereen die overwint...' Gods 'geduld' is echter niet van het laissez faire soort; het staat in contrast met Gods hartstochtelijke toewijding aan wat recht is en met Gods hartgrondige afkeer van halfslachtige houdingen $(2: 5,14-16,20-23 ; 3: 3,15)$.

Gods geduld - en ongeduld - is eerst en vooral voor de gemeenten aan wie het boek Openbaring gericht is, maar het strekt zich ook uit naar alle mensen, want de dienaren

33.Zie ook 8:3-5; "That we read now of "the prayers of all the saints" confirms our earlier contention that the picture of the martyrs under the altar in 6:9 is not a narrow reference to a group of literal martyrs but a figurative representation of all saints who suffer to whatever degree (this likewise confirms the same conclusion concerning the "overcomers" in the letters)' (Beale 1999:455).

34.'De bewoners van de aarde' verwijst naar de volgelingen van de Draak en het Beest; zie Bauckham (1993:239-241).

35.Ze rusten al, maar de situatie in de wereld is nog niet veranderd. Dit verwijst wel naar hen die gestorven zijn, zie 14:13, in tegenstelling met de volgelingen van het Beest die geen rust hebben; vuur en zwavel zijn de beelden voor hun toestand Beest die
$(14: 9-11)$.

36. In die zin ook Bauckham (1993:56): 'it is not just that there is an arbitrarily decreed quota of martyrs to be completed. It is so that the witness of the martyrs may play a key role in God's purpose of establishing his universal kingdom.' en broeders en zusters van hen die vermoord zijn worden opgeroepen om hun getuigenis in de wereld voort te zetten totdat het aantal martelaren volledig is. Gods macht toont zich in de getuigende gemeenten in de vorm van schijnbare onmacht zoals dit ook het geval was met Jezus, de betrouwbare getuige, de eerstgeborene van de doden en de heerser over de koningen der aarde (1:5). Zij hebben 'gezegevierd over de Draak door het bloed van het Lam, door het woord van hun getuigenis' (12:11), dat is door te volharden in de 'werken' van Jezus tot het einde (2:26), tot de dood toe. 'En zij hebben hem overwonnen door het bloed van het Lam en door het woord van hun getuigenis, en zij hebben hun leven niet liefgehad, tot in de dood' (12:11). De overwinning komt niet door de dood op zichzelf maar door effectieve trouw tot de dood. ${ }^{37}$ Deze aardse 'overwinning' van de getrouwen ziet er daarom op het eerste gezicht niet uit als de overwinning van een leeuw maar als die van een lam dat geslacht is, meer precies, het paaslam. ${ }^{38}$ Wat vereist is voor die overwinning wordt duidelijk samengevat in de woorden van de engel die het eeuwig evangelie verkondigt:

Heb ontzag voor God en geef hem eer, want nu is de tijd gekomen dat hij zijn oordeel zal vellen. Aanbid hem die hemel en aarde, zee en waterbronnen geschapen heeft. (Op 14:6)

De verliezers zijn zij die de Draak en het Beest aanbidden, zoals de derde engel het verwoordt in dramatische taal:

Als iemand het beest en zijn beeld aanbidt en het merkteken op zijn voorhoofd of zijn hand krijgt, zal hij de wijn van Gods woede moeten drinken, die onverdund in de beker van zijn toorn is geschonken. Hij zal in vuur en zwavel worden gepijnigd, onder de ogen van de heilige engelen en van het lam. De rook van die pijniging zal opstijgen tot in eeuwigheid. Wie het beest en zijn beeld aanbidden, of wie het merkteken van zijn naam draagt, ze krijgen geen rust, overdag niet en 's nachts niet. (Op 14:9-11)

Die beschrijving van de toekomst van de verliezers lijkt voor ons nu wel een voorbeeld van een buitensporige straf, van

37. Beale (1999.353) interpreteert de overwinning van Jezus als 'penal substitution' maar dit beperkt de betekenis van Jezus' dood. Het belangrijkste is wel Jezus' maar dit beperkt de betekenis van Jezus' dood. Het belangrijkste is wel Jezus' toewijding (liefde: 1:5;3:9) aan de zaak van God. De getrouwen zijn geroepen om
te delen in de werken van Jezus (2:26). Of zoals Beale (1999: 353 ) het uitdrukt: te delen in de werken van Jezus $(2: 26)$. Of zoals Beale $(1999: 353)$ het uitdrukt:
'While he was suffering the defeat of death, he was also overcoming it by creating a kingdom of redeemed subjects over whom he would reign and over whom the devil would no longer have power.' Jezus' handelen volgens de doelen van Gods schepping negeert de doelen van de sociale structuur en de instellingen van het Rijk en is in die zin een overwinning voor de schepping; delen in het handelen van Jezus is delen in die overwinning.

38.Zie Openbaring 5:5-6 waar een leeuw wordt aangekondigd, maar Johannes ziet in feite een lam. De aardse 'macht' en 'overwinning' van Jezus ziet er uit als die van een lam dat geslacht is; zijn huidige hemelse 'macht' is die van de universele rechter die komen zal (vergelijk Hand 10:42; 17:31). In die zin is hij het apocalyptische lam, dat zal oordelen en de macht heeft om het oordeel te laten uitvoeren. De vraag van Moyise (2001:184), 'Does the Lion lie down with the Lamb? Are we supposed to reinterpret the apocalyptic violence, with its note of violence and supposed to reinterpret the apocalyptic violence, with its note of violence and gloating, as symbolic of Christ's self-sacrifice?', moet wel negatief beantwoord
worden. De interpretatie van Beale (1999:353) is genuanceerd: 'Wherever the OT worden. De interpretatie van Beale (1999:353) is genuanceerd: 'Wherever the OT
predicts the Messiah's final victory and reign, John's readers are to realize that these goals can begin to be achieved only by the suffering of the cross.' Hij voegt er een belangrijke voetnoot aan toe: 'Similarly Caird, Revelation, 74-75, although he mistakenly leaves no room for a final, more literal defeat of the divine enemy. Bauckham (1993:183) schijnt ook niet genoeg aandacht te geven aan het komende oordeel en ziet alleen de offerdood: 'But that the victory in question [in 5:5] is not a military victory over the godless nations, nor even the destruction by judicial sentence that 4 Ezra expected, John establishes once for all by representing the messianic conqueror as a sacrificial lamb.' Als we dat offer begrijpen als het offer van het pasiam dan kunnen we zien dat het van het paaslam, dan kunnen we zien dat het effect van dit bloed zich zal tonen wanneer het de heiligen beschermt in het oordeel (zie 1 Tess 1:10), zoals he sraël beschermde in de crisis ten tijde van Mozes. Inderdaad, Jezus overwint de Draak door zijn trouw an God tot in de dood en door deze overwinning wordt $h$ door God aangesteld als de eschatologische rechter; zijn 'oordeel' en 'oorlog' zal die overwinning tegen de Draak effectief waarmaken in de nieuwe hemel en de nieuwe aarde, in the nieuwe Jeruzalem (19:11). 
machtsmisbruik. ${ }^{39} \mathrm{Om}$ deze scènes te begrijpen in hun context moeten we eerst de literaire tradities herkennen en de functie van zulke tradities. ${ }^{40}$ Een van de functies van deze tekst is waarschuwing en niet gewoonweg voorspelling. ${ }^{41}$ Dit past goed in het patroon van de twee wegen dat op verschillende manieren opduikt in Openbaring (Babylon-Jeruzalem) om de uitkomst van de weg naar de dood en de weg naar het leven dramatisch en beeldrijk voor te stellen. Openbaring 15:4 geeft uitdrukking aan de mogelijkheid en de hoop dat door het getuigenis van de gemeenten de volken de weg van het leven zullen kiezen. ${ }^{42}$

Voor de getuigen op aarde is de onmacht en de dood van het aardse Lam een beeld van hun eigen onmacht, maar daarmee opent Openbaring een nieuw, hemels of eschatologisch perspectief: de 'werken' van Jezus verwerkelijken de visie van de schepper, en in hun deelname aan die 'werken' tot de dood toe zijn de gelovigen machtig, want door hun werken wordt Satans macht ondermijnd. Binnen dit nieuw symbolisch kader wordt dringend verwacht ${ }^{43}$ dat zich in het oordeel spoedig de waarheid zal openbaren.

\section{Conclusie}

Volgens Thompson moet macht gezien worden in verhouding tot een sociale structuur, de instellingen die de doelen en waarden van de sociale structuur uitdrukken, en het handelen van mensen die zulke doelen bewerkstelligen of tegenwerken. Openbaring beroept zich op zijn macht als profetie om de macht van de sociale structuur (of ideologie) en instellingen (de troon) van het Rijk te ondermijnen door een alternatieve sociale structuur (God als schepper; Gods

39 . Dit is niet het onderwerp van deze bijdrage, maar het roept heel wat vragen op Teksten zijn geen 'objecten' die precies 'gemeten' kunnen worden, en teksten over God zijn nog meer 'onzeker' en 'onstabiel': ze kunnen op veel manieren gelezen worden zoals we kunnen zien in geschiedenis van hun 'receptie'. De keuze van het beeld van het oordeel om te spreken over Gods handelen heeft, zoals alle beelden, tot gevolg dat het de weg opent voor verdere vragen. In welke zin is God een 'rechtvaardige rechter'? Oordeelt God de mens zuiver en alleen volgen zijn werken (Op 2.23 $14 \cdot 13,20: 12,13,22: 12$ ? Is Gods straf louter pedagen zijn werken (Op 2.23,14.13,20.12, 13, 22.12)? Is Gods straf louter pedagogisch bedoeld? Speelt vergeldis rechtvaardigheid en Gods vera teksten gelezen werden (voor de rabbijnen, zie Urbach 1979:448-461). Origene was het brandpunt van de dist arme samenhangt (zie Sachs 1993). De 'rechtvaardiging' volgens Paulus was het hete onderwerp van de Reformatie. Alle 'lezingen' van een tekst zijn van belang als weg naar de betekenis voor hier en nu. In die zin volg ik Stendahl (2000:65), 'To me it became increasingly important to widen the gap between original meaning and what came to be or what may now be the meanings, often driven by mora sensitivities and insights not found in the text.'

40. Beschrijvingen van de hel en 'tours of hell' waren goed bekend in de apocalyptische literatuur, zie Himmelfarb (1983). Jesaja 66:24 is een van de 'inspirerende' teksten. Beale (1999:761-765) geeft een nuttige lijst van bijbelse en apocalyptische teksten.

41.'The warning in vv 6-11 is intended to motivate believers to persevere. Therefore $v 12$ is the main point of vv $6-12$, as with similar exhortations in $13: 10$ and $13: 18^{\prime}$ (Beale 1999:765). Hibbard (2011:357) verwijst naar Jona 3:8b-10 en toont aan dat de kern van profetie (reeds voor Jeremia) niet te vinden is in voorspelling maar de kern van profetie (reeds voor Jeremia) niet te vinden is in voorspelling maar worden bij de verschrikkelijke beelden van Openbaring: 'En zou ik dan niet begaan worden bij de verschrikkelijke beelden van Openbaring: 'En zou ik dan niet begaan
zijn met Nineve, de grote stad Nineve, waar zoveel mensen wonen - meer dan zijn met Nineve, de grote stad Nineve, waar zoveel mensen wonen - meer dan
twaalf tienduizendtallen - mensen, die het verschil tussen hun rechterhand en hun linkerhand niet weten, en ook nog zoveel dieren' (Jona 4:11)

42.Bauckham (1993:336-337) besluit zijn lange artikel met de woorden: '.... John's central prophetic conviction about the coming of God's kingdom on earth: that the sacrificial death of the Lamb and the prophetic witness of his followers are God's strategy for winning all the nations of the world from the dominion of the beast to his own kingdom.' Lambrecht (1998:219-220) beaamt dit: 'One should, however, not for thet that this vindication functions as a somewhat delayed but however, not for the positive answer to the marts of God that all punishments, except the last absolutely eschatological condemnation, are intended to bring about the conversion of the enemies.'

43.Zie vooral Openbaring 22:17, 20 . troon; Gods oordeel) op te roepen en zo een alternatief handelen (de 'werken' van Jezus) te stimuleren. In deze visie is God de schepper van alles wat bestaat en zijn oordeel zal alles bevestigen wat de waarden en doelstellingen van de schepper uitdrukt; 'hun werken volgen hen' (14:13). ${ }^{44}$ De Draak symboliseert de illusie van de drang naar eigenmacht van Satan, die op zijn beurt een nieuwe afhankelijkheid propageert met een vernielend effect op de schepping. Openbaring herkent deze illusie van Satan in de mythologie en propaganda van het Romeinse Rijk en ook in de illusies van rijkdom en zelfvoldaanheid in de gemeente van Laodicea (3:14-20). De ware macht is Gods macht en het is een scheppende macht. Openbaring is een oproep tot getuigenis, gericht aan de gemeenten, waardoor de mensen Gods korte tijd van genade moeten beantwoorden met bekering. De gemeenten en alle mensen worden op een dramatische manier geconfronteerd met de twee wegen, leven of dood, Babylon of Jeruzalem. De onmacht van de gemeenten reflecteert de onmacht van Jezus' aardse leven, maar ondanks die onmacht en dood is hun deelname aan de 'werken van Jezus' al het begin van de overwinning op de Draak. De keuze van een zekere nadruk op de 'werken' in Openbaring suggereert dat de gelovigen niet zomaar slachtoffers zijn van de geschiedenis, maar in feite actief deelnemen in Jezus aan het scheppingsproject. Het antwoord van de mensen op hun getuigenis mag voor het ogenblik negatief lijken, maar Openbaring garandeert het succes van het scheppingswerk door Gods 'oordeel' en Gods 'oorlog' tegen de Draak.

\section{Tegenstrijdige belangen}

De auteur verklaart geen financiële of persoonlijke belangen te hebben die hem ongepast kunnen hebben beïnvloedt bij het schrijven van dit artikel.

\section{Literatuurverwijzingen}

Aune, D.E., 1983, Prophecy in Early Christianity and the Ancient Mediterranean World, Eerdmans, Grand Rapids, MI.

Aune, D.E., 1997, Revelation 1-5, Word Books, Dallas, TX. (Word Biblical Commentary, vol. 52A.)

Aune, D.E., 1998, Revelation 6-16, Word Books, Dallas, TX. (Word Biblical Commentary, vol. 52B.)

Aune, D.E., 1998, Revelation 17-22, Word Books, Dallas, TX. (Word Biblical Commentary, vol. 52C.)

Barr, D.L., 2001, 'Waiting for the End that never Comes: The Narrative Logic of John's Story', in S. Moyise (ed.), Studies in the Book of Revelation, pp. 101-112, T \& T Clark, Edinburgh.

Bauckham, R., 1993, The Climax of Prophecy: Studies on the Book of Revelation, T \& T Clark, Edinburgh.

Beale, G.K., 1999, The Book of Revelation: A Commentary on the Greek Text, The New International Greek Testament Commentary, Eerdmans, Grand Rapids, MI.

Biguzzi, G., 1996, I settenari nella struttura dell'Apocalisse: Analisi, storia della ricerca, interpretazione, Suppl. Rivista Biblica, vol. 31, Edizioni Dehoniane, Bologna.

Bovati, P., 1994, Re-establishing Justice: Legal Terms, Concepts and Procedures in the Hebrew Bible, transl. M.J. Smith, Journal for the Study of the Old Testament, suppl. ser., vol. 105, Sheffield Academic Press, Sheffield.

Carey, G., 2001, 'The Apocalypse and Its Ambiguous Ethos', in S. Moyise (ed.), Studies in the Book of Revelation, pp. 163-180, T \& T Clark, Edinburgh.

Decock, P.B., 'The Works of God, of Christ, and of the Faithful in the Apocalypse of John', Neotestamentica 41, 37-66.

44.Aune (1998:839) verwijst naar de Mishnah Abot 6:9: "Moreover at the time of a man's departure, neither silver nor gold nor precious stones nor pearls go with him, but only [his knowledge of] the Law and good works.' Vergelijk ook 1 Korinthiërs 3:13. 
De Boer, M.C., 1988, The Defeat of Death: Apocalyptic Eschatology in 1 Corinthian 15 and Romans 5, Journal for the Study of the Old Testament, suppl. ser., vol. 22 JSOT Press, Sheffield.

Heil, J.P., 1993, 'The Fifth Seal (Rev 6, 9-11) as a Key to the Book of Revelation', Biblica $74,220-243$.

Hibbard, J.T., 2011, 'True and False Prophecy: Jeremiah's Revision of Deuteronomy', Journal for the Study of the Old Testament 35, 339-358. http://dx.doi org/10.1177/0309089211398647

Himmelfarb, M., 1983, Tours of Hell: An Apocalyptic Form in Jewish and Christian Literature, Fortress, Philadelphia, PA.

Lambrecht, J., 1998, 'The Opening of the Seals (Rev 6, 1-8, 6)', Biblica 79, 198-220.

Levenson, J.D., 1994 [1988], Creation and the Persistence of Evil: The Jewish Drama of Divine Omnipotence, Princeton University Press, Princeton, NJ.

Sachs, J.R., 1993, 'Apocatastasis in Patristic Theology', Theological Studies 54, 617-640.

Schüssler Fiorenza, E., 2001, 'The Words of Prophecy: Reading the Apocalypse Theologically', in S. Moyise (ed.), Studies in the Book of Revelation, pp. 1-19, T \& T Clark, Edinburgh.
Schüssler Fiorenza, E., 2008, 'Reading Scripture in the Context of Empire', in C. Briggs Kittredge, E. Bradshaw Aitken \& J.A. Draper (eds.), The Bible in the Public Square: Reading the Signs of the Times, pp. 157-171, Fortress Press, Minneapolis, MN.

Stendahl, K., 2000, 'Dethroning Biblical Imperialism in Theology', in H. Räissänen et al. (eds.), Reading the Bible in the Global Village, pp. 61-66, Society of Biblical Literature, Atlanta, GA.

Tate, M.E., 1992, 'Satan in the Old Testament', Review and Expositor, 89, 461-474.

Tonstad, S.K., 2006, Saving Gods Reputation: The Theological Function of Pistis lesou in the Cosmic Narratives of Revelation, T \& T Clark, London. (Library of New Testament Studies, vol. 337.)

Thompson, J.B., 1981, Critical Hermeneutics: A Study in the Thought of Paul Ricoeur and Jürgen Habermas, Cambridge University Press, Cambridge.

Urbach, E.E., 1979, The Sages: Their Concepts and Beliefs, 2nd edn., Magnes Press, Jerusalem.

Van Schaik, A.P., 1971, De Openbaring van Johannes, Romen, Maaseik. 